\title{
THE SOCIAL CONSTRUCTION OF HIV/AIDS
}

\author{
Ms Natalie Goldstein \\ MA (Psych) \\ Department of Psychology, RAU
}

\author{
Prof HG Pretorius \\ D. Litt. et Phil. \\ Vice-chairperson, Department of Psychology, RAU \\ Corresponding author: hgpr@lw.rau.ac.za
}

\section{Prof AD Stuart}

D. Litt. et Phil.

Chairperson, Department of Psychology, RAU

Keywords: social construction; HIV; AIDS; meaning making; preparation for death

\begin{abstract}
An in-depth look is taken at the specific discourses surrounding the debilitating HIV/AIDS epidemic sweeping South Africa and the world. Not only is the statistics daunting, the incidence of the HIV infection worldwide is staggering. This article provides a concise definition of what a discourse entails as well as its impact on the perceptions concerning the epidemic and its treatment. It looks at the cultural meanings contributed to the infection, its etiology and progress. The role of cultural schemas and means of explanation are examined as well as the gender roles that are used to organise ideas around sexuality and the individual expression of that sexuality. The article securely situates the HIV/AIDS debate within the larger political structures forming today's world. It clearly implicates historic discourses in the modern day perceptions regarding the disease. In the final instance it becomes clear that any interpretation of the experience of HIV/ AIDS has to incorporate the effects of culture, gender and broader political structures on individuals' responses to and understanding of the disease.
\end{abstract}

\section{OPSOMMING}

Hierdie artikel poog om 'n indiepte ondersoek te loods na die spesifieke diskoerse rondom die MIVIVIGS epidemie in Suid-Afrika en die wêreld. Wêreldwyd is die statistiek rondom die epidemie oorweldigend en die groeiende voorkoms daarvan onrusbarend. Dié artikel bied eerstens 'n omvattende definisie van wat diskoerse behels asook die impak daarvan op die persepsies van die infeksie en die behandeling daarvan. Kulturele skemas en verduidelikings van MIVIVIGS word ondersoek asook die geslagsrolle wat gebruik word om idees rondom seksualiteit en die uitlewing van hierdie individuele seksualiteit te verklaar. Die artikel plaas die epidemie binne die groter politieke strukture wat die daaglikse omgewing vorm en bied duidelike bewyse vir die invloed van die land se historiese verlede op die hedendaagse persepsie van MIVIVIGS. Uiteindelik is dit duidelik dat enige poging om die subjektiewe ervaring van MIVIVIGS te bekyk, die effek van kultuur, geslag en die breër politieke arena sal moet inagneem om sodoende die individue se ervarings van, en reaksies op, die infeksie te begryp. 


\section{INTRODUCTION}

HIV/AIDS is an epidemic of grave proportions. While much remains ambiguous and equivocal regarding the condition, it is unequivocally complex and tragic. HIV/ AIDS has created untold anguish and tremendous social tragedy. The statistics are daunting and in turn provide a general sense of the full ramifications of the pandemic (Brandt, 1988a). HIV/AIDS has infected 50 million individuals, killing over 16 million people (UNAIDS, 1999). In 1999 AIDS deaths reached a 2.6 million figure globally, with a further 5.6 million adults and children becoming infected (UNAIDS, 1999). Furthermore, the statistics in South Africa reveal frightening facts. It is predicted that over 1500 South Africans are infected with HIV daily, suggesting that one in eight adults (15-49 years of age) is infected with HIV in South Africa (South African Health Review, 2000). With a total of 4.2 million infected people, South Africa has the largest percentage of people living with HIV/AIDS in the world (UNAIDS, 2000). In turn, these alarming figures warrant an exploration and examination of the personal, social and cultural experience and discourses associated with HIV/AIDS.

Before an exploration of the various discourses apparent in the construction of HIV/AIDS may be undertaken it is important to note what is meant by discourse. Accordingly, it may be suggested that the way in which one comprehends, conceives, voices and makes meaning of the world, transpires through discourse, language and interactions that are discursive. Thus, meanings, perceptions, understandings and knowledge of the world are not pre-given, but rather actively constructed (Burr, 1996).

It is important to note that rather than naturally occurring instances of mere meaning, language and culture are the executions of power whereby specific accounts of the world are actively sanctioned, while others are silenced and dismissed. Language endows the individual with certain understandings, meanings and sets of knowledge which allow certain statements to be understood as reasonable, powerful, and honest while others are perceived as ludicrous, inane and even threatening (Burr, 1996). Consequently, discourse enables and restricts categories of personhood. In turn, it is through discursive methods that one may come to self-knowledge, experience and understanding.
Discourse regulates forms of experience and perception. Consequently, one does not understand, perceive and know oneself in any way one chooses but rather one's perceptions and understanding are constructed while simultaneously being limited by available discursive understandings. Discourse both restricts and enhances meaning, dialogue and thinking (Parker, 1992; Burr, 1996). Thus, discourse produces categories of personhood and types of experience (Burr, 1996).

Accordingly, in the field of psychology and illness, Crystal and Jackson (1992) note that diseases are not mere biological entities but rather socially constructed phenomena. Concurringly, Crimp (1988:3) suggests that: "AIDS does not exist apart from the practices that conceptualize it, represent it and respond to it. We know AIDS only through those practices. This assertion does not contest the existence of viruses, antibodies, infections or transmission routes. Least of all does it contest the reality of illness, suffering and death. What it does contest is the notion that there is an underlying reality of AIDS upon which are constructed the representations, or the culture, or the politics of AIDS. If we recognize that AIDS exists only in and through these constructions, then hopefully we can also recognize the imperative to know them, analyze them and wrest control of them".

HIV/AIDS may be understood through its social constructions that work to influence both private and public experiences and reactions to the illness. Specifically, Crystal and Jackson (1992) note that one aspect of the social construction of HIV/AIDS revolves around disease definitions bound up with the experience. The terminology commonly used to describe the experience of HIV/AIDS often makes use of the synecdoche AIDS, even when HIV is really meant. The consequences of this AIDS synecdoche are meaningful. This socio-linguistic construction emphasises the acute disease model of the HIV/AIDS illness, focusing on the terminal, debilitating and stigmatising consequences of the condition. Thus, the language used to talk about HIV/AIDS focuses on people dying from AIDS rather than on people living with HIV (Crystal \& Jackson, 1992). This in turn creates a sense of self that is impotent, helpless and hopeless (Tegius \& Ahmed, 1992). 
Plummer (in Snyman, 1999) suggests that there are two central discourses which order much of the "HIV/ AIDS language". One centers on the medicalisation of HIV/AIDS and the other, the stigmatisation of HIV/ AIDS. The medicalisation focuses on death and "serves to entrench the power of medicine and science leaving individuals disempowered to take responsibility for managing the illness themselves" (Plummer in Snyman, 1999:13). The other focuses not on the medical condition per se, but rather views HIV/AIDS in terms of a visible, stigmatised condition inevitably advancing towards death (Sontag, 1991).

A common response to the disease and the fear of contagion is a moralistic theme of punishment. This theme has impacted on the consciousness of common perceptions of HIV/AIDS seen as "divine retribution" for the sin of sexuality (Sontag, 1991; Dansky, 1994). Thus, people with HIV/AIDS are seen as victims and are located on a continuum of "innocence" or "guilt" and therefore of "deserving" or "non-deserving" of the disease (Dansky 1994). Sontag (1991) suggests that HIV/AIDS summons up an older metaphor analogous with syphillis; that of pollution. Thus, plague has become the principal metaphor by means of which HIV/ AIDS has been understood. Sontag (1991) suggests that the notion of plague has been used metaphorically as the highest, symbol of collective evil, calamity or punishment. Dansky (1994:38) adds that "the essence of stigma is the complementary, dual symbolisation of moral and physical chaos embodied in a reciprocal interrelationship. The stigmatised are deviates, branded (as in Karposi's Sarcoma) and corrupted".

Gilman (1988:88) notes that: "Icons of disease appear to have an existence independent of the reality of any given disease. This free-floating iconography of disease attaches itself to various illnesses in different societies and at different moments in history. Disease is thus restricted to a specific set of images, thereby forming a visual boundary, a limit to the idea (or fear) of disease. The creation of the image of AIDS must be understood as part of this ongoing attempt to isolate and control disease". In explaining this boundary Gilman (1988) explains that early conceptions of HIV/AIDS came to view it as a "gay" disease. This in turn structured the understanding of AIDS in a very marked manner. Consequently, PWA (Persons with AIDS) were stigmatised as carriers of infectious disease as well as located within a very specific category of sexual orientation (Douard, 1990). As a result, Gilman (1988) notes that HIV/AIDS was understood as a subset of sexually transmitted diseases (STDs), as well as a disease which afflicted gay individuals as a result of their sexual practices and lifestyle. In turn, HIV/AIDS came to be viewed as an illness afflicting "those who willfully violated the moral code ... a punishment for sexual irresponsibility" (Gilman, 1988:91). Watney (1987:9) noted that HIV/AIDS was "not only a medical crisis on an unparalleled scale, it involves a crisis of representation itself, a crisis over the entire framing of knowledge about the human body and its capacities for sexual pleasure". Thus, Crewe (1992) suggests that HIV/AIDS confronts society with its prejudices, stereotypes and discrimination. It is fitting to note Fee and Fox's (1988:i) referral to HIV/AIDS namely that "We have learned very little that is new about the disease, but much that is old about ourselves".

Sontag (1991:26) adds that because HIV/AIDS is "An infectious disease whose principal means of transmission is sexual puts at greater risk those who are more sexually active - and is easy to view as a punishment for that activity". Those infected with the disease thus come to experience shame and isolation. Miller (1998) notes that the meaning that an infected individual gives to seropositivity influences this person's sense of self. Often individuals with HIV/AIDS infection are unable to discern between their sense of self and the virus, in turn self-labelling themselves as "diseased", "infected" or "contaminated". This perception may create a sense of isolation and non-belongingness (Dansky, 1994). In turn negative self-talk may be linked to depression, isolation and apathy which activates the stress response (Miller, 1998). This same author further notes that in recreating an inner reality, people choose their internal messages, separate the "me" from the "you" and rewrite their past and present stories, establishing a script for the future.

\section{HIV/AIDS AND CULTURE}

Marsella and White (1982:3) propose that "illness experience is an interpretative enterprise which is constructed in social situations according to the premises of cultural 'theories' about illness and social behaviour generally". IIIness and HIV/AIDS specifically may be interpreted and experienced in variable ways 
depending on the cultural codes available for reasoning about them (Marsella \& White, 1982). Accordingly, one's experience of HIV/AIDS is a culturally mediated experience. Thus, while experienced privately, the form which meaning takes on is influenced by one's participation in a specific culture (Bruner, 1990; Joshephson, 2000). Culture provides the PWA with the tools with which he/she may conceptualise his/her existential crisis. Correspondingly, differences in worldviews translate into differences in the experience of HIV/ AIDS.

Fee and Fox (1988:121) suggest that: "Just as cultural conceptions of disease may be embodied in the framing of scientific theories, so these theories also influence popular perceptions of disease. At times, such scientific theories may reinforce, or contradict, other cultural conceptions, for example, religious and moral ideas, or racial stereotypes. The aspects of disease that we call 'social' and 'biological' are parts of a single social reality in which disease is produced, experienced, and reproduced, and in which the cultural meanings of the experience are defined, acted upon, and struggled over".

Webb (1997) notes that community perceptions and individual perceptions of HIV/AIDS incorporate culturally specific beliefs relating to its origins and etiology, risk perception and attitudes towards those infected. The nature of one's response to "HIV/AIDS is in part conditioned by the macro determinants of HIV epidemiology, the behavioural context of sexual activity and the heterogeneity within the social make-up of communities, expressed through the responses of individuals" (Webb, 1997:158). Similarly, O'Connor (in Ungvarski \& Flaskerud, 1999) notes that culture and ethnicity are significant determinants of individuals' perceptions and understanding of HIV/AIDS.

O'Connor (in Ungvarski \& Flaskerud, 1999) notes that HIV/AIDS affects significant aspects of life that have cultural meaning specifically reproduction, birth, death, the role of women and sexuality. Furthermore, because HIV/AIDS is a sexually transmitted disease that has a long incubation period, a terminal prognosis and constantly changing scientific knowledge; it is often subject to alternative lay beliefs and explanations which might contradict current medical and/or scientific knowledge at any stage. These new understandings are frequently couched in existing lay explanations of the cause, transmission, prevention and treatment of disease. Thus, cultural world views gain much force and tenacity (Ungvarski \& Flaskerud, 1999:328). These cultural values and interpretations in turn manifest in behaviour and attitudes, which may be potentially dangerous; at times reinforcing stereotypes, stigmatisation and isolation of PWAs as well as reinforcing participation in potentially dangerous behaviour (Ungvarski \& Flaskerud, 1999).

Rosenberg (1988:27-28) suggests that HIV/AIDS: "reminds us that biological mechanisms define and constrain social response ... this new disease reflects both elements-the biological and cultural .... Only the sophisticated tools of modern virology and immunology have allowed it to be defined as a clinical entity; yet its presumed mode of transmission and extraordinary fatality levels have mobilised deeply felt social attitudes that relate only tangentially to the virologist's understanding of the syndrome". Thus, Fee and Fox (1988:5) suggest that this "disease reflects and lays bare every aspect of the culture in which it occurs".

Lawson (1999) posits that socially and culturally related risk factors in the transmission and experience of HIV/ AIDS need to be identified and explored. Concurringly, Fishbein (2000) notes that cultural notions and perceptions play a role in influencing behaviour. Van Dyk (2001) reports that in Africa witchcraft is believed to be a causal agent in HIV transmission and AIDS. Bond (in Van Dyk, 2001) and Yamba (in Van Dyk, 2001) found that $18 \%$ of Zambian participants named witchcraft as the cause of deaths in their village, including deaths caused by AIDS. More than 25\% ascribed sexually transmitted diseases to witchcraft.

Yamba (in Van Dyk, 2001) notes that the use of witchcraft as the source of blame for HIV/AIDS is an attempt to make sense of existence in an age of unexplainable illness. Witchcraft in turn serves to explain the untimely death of young individuals attributable to HIV/AIDS, in a society, which comprehends untimely death as the work of evil spirits and witches. Van Dyk (2001) notes that the externalisation of blame may be protective, preventing guilty feelings and in turn alleviating anxiety. Belief in witches, provides people with meaning and potential answers that science cannot give (Van Dyk, 2001). 
However, while witchcraft beliefs do have potential protective dimensions they may have negative implications for AIDS education as they promote the externalisation of blame and they do not encourage the activation of precautionary actions or "safe" sex behaviours (Van Dyk, 2001).

Furthermore, Green (in Van Dyk, 2001) in a study conducted in Uganda notes that while HIV/AIDS education in Uganda is widespread and condoms are widely distributed, only $3 \%$ of Ugandan men use condoms. Taylor (in Van Dyk, 2001) similarly found that while Rwandan people were educated about the perils of HIV/AIDS, none of the participants in the study used condoms. Taylor (in Van Dyk, 2001) concluded that the choice not to use condoms was this lack related to culture rather than ignorance. Taylor (1990, in Van Dyk, 2001) noted that most Rwandans believe the exchange of bodily fluid that occurs during sexual intercourse is viewed as the exchange of "gifts of the self"; an essential component in a relationship. Most Rwandans, believe that the use of condoms will intercept and disturb this process with potential negative consequences for the relationship.

Furthermore, Heald (in Van Dyk, 2001) and Schoepf (in Van Dyk, 2001) note that a common belief espoused by many African cultures is the notion that repeated contributions of semen ripen the growing foetus and condoms therefore conflict with this activity, which could be potentially harmful to foetal development according to these cultural perceptions. Furthermore, semen is also considered to contain vitamins necessary for physical and mental health, as well as for the future fertility of women (in Van Dyk, 2001). Using condoms would thus also deprive women from obtaining these perceived benefits from semen.

Lawson (1999) notes that traditional practices in Africa, specifically circumcision, the sexual mutilation of women, ritual sacrifices and various skin perforations by traditional healers, may act as potential modes of HIV/AIDS transmission. Ashforth (2001) recognises that cultural and religious traditions complicate reactions to HIV/AIDS and that cultural taboos around sexual talk hinder possibilities of encouraging communication around safe sex. Similarly, cultural constructions of gender force women to maintain subordinate positions, again disallowing for the negotiation of safe sex. While cultural notions around masculinity endorse participation in polygamous relationships, these notions also play significant roles in the spread of HIV/AIDS (Ashforth, 2001). Thus, it becomes apparent that the social context within which HIV/AIDS is spreading and responded to is both influenced, created and interpreted by culture (Webb, 1997).

Following the notion of the cultural specific experience of HIV/AIDS, healing too becomes understood to be a cultural phenomenon. Accordingly, the traditional African world view, comes to view healing as a religious phenomenon (Staugard, in Saayman \& Kriel, 1992). The role of bacteria and infection, is viewed as secondary in the causation of illness. Furthermore, health can only be returned once an individual belongs to a healthy community (Saayman \& Kriel, 1992). Accordingly "a person is a person through other persons" (Saayman \& Kriel, 1992:35). Such a healthy community is one where a balance exists between living people, the living-dead (ancestors), and their environment. Thus, because disease is viewed as being socio-cultural in origin, its presence poses a threat to the community at large, as it symbolises disorder and disharmony (Saayman \& Kriel, 1992). Once an individual falls ill within the community it becomes the task of the medicine man or woman to determine what the cause of the illness is and to determine the route for cure. Healing takes on a public quality as it is characterised by prayers, sacrifices and taking of medication (Saayman \& Kriel, 1992). Thus, it appears as though what is to be healed is not simply the individual but the entire community.

Contrarily, Western medicine prescribes to an explanatory model, which relies on science and logical positivism. Accordingly, the sick individual is understood as a biological organism, comprising various components. Sickness is a function of the breaking down or malfunctioning of one or more of the body parts (Saayman \& Kriel, 1992). When humans fall ill "the cause is searched for in indisputable facts rather than in questionable values" (Bosch, in Saayman \& Kriel, 1992:40). Cure involves medical intervention, concerning mainly the sick individual rather than the community at large (Saayman \& Kriel, 1992). Louw (1994) notes that the Western model of health denotes an analytical and diagnostic approach to the individual's 
health.

Cultural contrasts in comparison of Western and NonWestern views of mind and body are closely linked with cultural ways of interpreting personal and social experiences (Marsella \& White, 1982; Airhihenbuwa, Makinwa \& Obregon, 2000). Accordingly, Marsella and White (1982) suggest that culture provides individuals with the tools to reduce cognitive tasks by providing them with the selective use of available information. Culture provides the individual with "implicit rules specifying what to attend to, how to take cognitive shortcuts, and how to make reasonable inferences in the face of complex, disparate and often contradictory information" (Marsella \& White, 1982:8). Hence, culture determines the manner in which perception and in turn meaning is organised (Airhihenbuwa et al. 2000). Accordingly, it seems obvious that it "is crucial to approach [HIV]/AIDS as a disease of society, of political economy ... culture [and gender]" (Webb, 1997:39).

\section{THE GENDERED EXPERIENCE OF HIV/ AIDS}

Biology makes women anatomically and physiologically more vulnerable to contract HIV/AIDS than men. Biology is further complicated by the social meanings and understandings intimately connected and intertwined with gender and sex (Wilton, 1997). In this regard Wilton (1997:6) notes that: "The set of meanings most ineradicably encoded within, by means of sexual behaviours and the social proscriptions and prescriptions which cohere around such behaviours are those to do with gender. It is not possible to disengage gender and the erotic or to consider the politics of the sexual in isolation from sexual politics".

Furthermore, Wilton (1997) proposes that sex is not merely an instinctive, biological behaviour but is socially constructed in complex and symbolic ways (Campbell \& Hayes, 1998).

Wilton (1997) suggests that class, gender, race, age and nationality have a significant influence on how one organises one's sexual self. More specifically, this author suggests they influence the manner in which one chooses to engage with sexual partners and impact upon the agency and power that one has in terms of one's sexuality and sexual practices. Subsequently, in the case of HIV/AIDS gender plays a significant role in the extent to which one is able or allowed to take agency in protecting oneself against HIV infection (Wilton, 1997; Patton, 1994).

Biologically penile penetration puts women at risk of pregnancy, cervical cancer, venereal diseases and HIV. Socially women tend to wield little power within heterosexual relationships. Wilton (1997) notes that the majority of women are economically dependent on male family members influencing their claim to power and certain rights (Wilton, 1997; Strebel, 1992). Correspondingly, women are at risk as a result of their inability to negotiate for safe sex (Wilton, 1997). Grundlingh (2001) similarly, refers to a gendered experience of HIV/AIDS. He notes that women are not only anatomically nor physiologically vulnerable; women in South Africa in particular are socio-economically vulnerable to HIV infection. Grundlingh (2001) notes that in South Africa as a result of urbanisation and its concomitant manifested breakdown of traditional family life, it is common for men to participate in polygamous relationships, increasing the risk of infection. Furthermore, Preston-Whyte (in Glover-Walton, 2001) notes that when women do choose to participate in safe sex, they might be constructed as diseased or dishonourable. PrestonWhyte (in Glover-Walton, 2001) notes that in South Africa the carrying of condoms by women is often taken as evidence of being promiscuous and/or as being HIV-positive.

The identification of socio-cultural practices clarifies some of the problems specific to women, which may encourage behaviour conducive to the spread of HIV/ AIDS. These problems relate to movements of individuals or groups, fertility practices and the subordinate position of women. Thus, the increased vulnerability of women to infection may be ascribed to socio-cultural factors which place women in a particularly difficult position to act in ways which could protect them from becoming infected with HIV (Lawson, 1999).

\section{THE POLITICAL ECONOMY OF HIV/AIDS}

In exploring the experience of HIV/AIDS it becomes apparent that individual experiences cannot be divorced from public reactions and constructions of the disease. Similarly, this is intertwined with the socio-political 
context from within which the disease is framed and understood. Thus explanations of perceptions at an individual scale are often to be located within political structures (Webb, 1997).

Grundlingh (2001) notes that it thus becomes important to examine the spread and understanding of HIV/AIDS within a specific context. Particularly, he notes that in South Africa HIV/AIDS became established during South Africa's Apartheid political regime. Grundlingh (2001) notes that at first HIV/AIDS in South Africa was viewed as being a homosexual disease, a disease of drug addicts and later on a disease afflicting the Black communities. Thus the history of HIV/AIDS in South Africa is rooted within a framework couched in a discourse of deviancy and scapegoats. In turn there was no urgency in addressing HIV/AIDS. The political response of South Africa to the HIV/AIDS epidemic has been "one characterised by denial, ministerial wrangling, the misallocation of resources and has been muted by those forces either resisting or pushing for political transformation" (Webb, 1997:71). Thus, HIV/ AIDS in South Africa exposed and intensified social prejudices, stereotypes, economic inequalities, discriminatory practices and political injustices (Grundlingh, 2001).

Brandt (1988a:417) suggests that: "Although the cause of AIDS is known the disease is richly metaphorised. While the meaning of disease is ever changing given our modes of explaining and accounting for the phenomena, illnesses continue to attract the most powerful social and political meanings. Indeed, disease is rife with meanings. The medical sciences and humanities offer the potential for deciphering and perhaps bending these meanings. By demonstrating the process by which biology and culture interact, the precise nature of the social construction of disease may be revealed. This is not to argue that disease is purely a relative phenomenon, merely constructed by certain privileged knowledge. Rather, it suggests that so complex a phenomenon as disease cannot be understood outside the culture in which it occurs. The biological world is fundamentally transformed by culture and politics".

\section{CONCLUSION}

Multiple variations of the experience of illness are discovered across cultures in the social organisation, personal experience and consequences of emotions and disorder (Kleinman \& Good, 1985). "They are organized differently as psychological realities, communicated in a wide range of idioms, related to quite different local contexts of power relations, and are interpreted, evaluated, and responded to as fundamentally different meaningful realities" (Kleinman \& Good, 1985:492). Accordingly, it becomes apparent for the necessity to explore and examine individual frames of reference and social relations (Kleinman \& Good, 1985). Thus, cross-cultural analysis of HIV/AIDS involves moving across multiple discourses or ways of talking about emotion and illness (Good, Good \& Moradi, 1985).

An interpretive explication of HIV/AIDS begins with the identification of culture as the tool that constructs and interprets one's response to and understanding of reality (Good, 1994). This reality may be both external - the natural world, social formations - or internal - one's subjective reality. Physical sensations and emotions are experienced as realities commanding the work of culture to bring them to meaning (Good et al. 1985). HIV/AIDS is experienced by the individual as "a set of symptoms or a condition expressed and interpreted in local idioms and using explanatory models" (Good et al. 1985:381). It is then further interpreted and labeled secondarily by family members and others. Thus, HIV/ AIDS may be viewed as an interpreted disorder, understood in terms of those culturally shared forms of interaction extrinsic to the individual from which they acquire their meaning (Phillips, 1994).

Brandt (1988b:168) notes that: "AIDS is an unfinished chapter in our medical and social history, demonstrating the nature of contemporary biomedical science and research; our beliefs about health, disease, and contagion; and our ideas about sexuality and social responsibility. AIDS demonstrates how economics and politics cannot be separated from disease; indeed, these forces shape our response in powerful ways. In the years ahead we will, no doubt, learn a great deal more about AIDS and how to control it. We will also learn a great deal about the nature of our society from the manner in which we address the disease: AIDS will be a standard by which we may measure not only our medical and scientific skill but also our capacity for justice and compassion". 
This article has attempted to explore the ways people come to make sense and meaning of their HIV/AIDS status as constrained by culture, gender and politics. It has attempted to elucidate some of the prominent discourses surrounding HIV/AIDS and to examine the ways in which these interpretations shape the experience of HIV/AIDS in profound and powerful ways.

\section{REFERENCES}

AIRHIHENBUWA, CO; MAKINWA, B \& OBREGON, R 2000: Toward a new communication framework for HIV/AIDS. Journal of Health Communication, 5:101-111.

ASHFORTH, A 2001: AIDS, witchcraft, and the problem of public power in post-Apartheid South Africa. Paper presented at the AIDS in Context International Conference (4-7 April 2001), at the University of the Witwatersrand, Johannesburg.

BRANDT, AM 1988a: AIDS and metaphor: towards the social meaning of epidemic disease. Social Research, 55 (3):413-432. BRANDT, AM 1988b: AIDS: from social history to social policy. (In: Fee, E and Fox, DM eds. 1988: AIDS: the burdens of history. Berkeley: University of California).

BRUNER, J 1990: Acts of meaning. Cambridge: Harvard University. BURR, V 1996: An introduction to social constructionism. London: Routledge.

CAMPBELL, C \& HAYES, G 1998: Evaluating HIV prevention programmes: conceptual challenges. Psychology in Society, 24:57-68.

CREWE, M 1992: AIDS in South Africa: the myth and the reality. London: Penguin.

CRIMP, D 1988: AIDS: cultural analysis, cultural activism. (In: Crimp, D ed. 1988: AIDS: Cultural analysis, cultural activism. Cambridge: Massachusetts Institute of Technology).

CRYSTAL, S \& JACKSON, M 1992: Health care and the social construction of AIDS: the impact of disease definitions. (In: Huber, J \& Schneider, BE eds. 1992: The social context of AIDS. London: Sage).

DANSKY, SF 1994: Now dare say everything! Tales of HIV-related psychotherapy. New York: Harrington Park.

DOUARD, J 1990: Stigma and privacy. AIDS Public Policy Journal, 5:37-41.

FEE, E \& FOX, D 1988: Introduction: AIDS, public policy, and historical inquiry. (In: Fee, E and Fox, DM eds. 1988: AIDS: the burdens of history. Berkeley: University of California).

FISHBEIN, M 2000: The role of theory in HIV prevention. AIDS Care, 12 (3):273-278.

GILMAN, SL 1988: AIDS and Syphilis: the iconography of disease. (In: Crimp, D ed. 1988: AIDS: cultural analysis, cultural activism. Cambridge: Massachusetts Institute of Technology).
GLOVER-WALTON, CA 2001: HIV/AIDS behavioural changes in Eastern Cape. Paper presented at the AIDS in Context International Conference (4-7 April 2001), at the University of the Witwatersrand, Johannesburg.

GOOD, BJ 1994: Medicine, rationality and experience. An anthropological perspective. Cambridge: Cambridge University. GOOD, BJ; GOOD, MJD \& MORADI, R 1985: The interpretation of Iranian depressive illness and dysphoric affect. (In: Kleinman, A and Good, B eds. 1985: Culture and depression: studies in the anthropology and cross-cultural psychiatry of affect and disorder. Berkley: University of California).

GRUNDLINGH, L 2001: A critical historical analysis of government responses to HIV/AIDS in South Africa as reported in the media, 1983-1994. Paper prepared for AIDS in Context International Conference (4-7 April 2001), at the University of the Witwatersrand, Johannesburg.

JOSHEPHSON, NE 2000: Exploring the narratives of therapists who work with HIV positive therapists. Unpublished MA Dissertation: Auckland Park: Rand Afrikaans University.

KLEINMAN, A \& GOOD, B 1985: Meanings, relationships, social affects: historical perspectives on depression. (In: Kleinman, $A$ and Good, B eds. 1985: Culture and depression: studies in the anthropology and cross-cultural psychiatry of affect and disorder. Berkeley: University of California).

LAWSON, A 1999: Women and AIDS in Africa: socio-cultural dimensions of the HIV/AIDS epidemic. Oxford: Blackwell.

LOUW, D 1994: Illness as crisis and challenge: guidelines for pastoral care. Doornfontein: Orion.

MARSELLA, AJ \& WHITE, GM 1982: Cultural conceptions of mental health and therapy. Dordrecht: D Reidel.

MILLER, AH 1998: Psychoneuroendocrinology. neuroendocrine and immune system interactions in stress and depression. Psychiatric Clinics of North America, 21 (2):443-461.

PARKER, I 1992: Discourse dynamics: critical analysis for social and individual psychology. London: Routledge.

PATTON, C 1994: Last served? Gendering the HIV pandemic. London: Taylor \& Francis.

PHILLIPS, 1994: On flirtation. London: Faber \& Faber.

ROSENBERG, E 1988: Disease and social order in America: perceptions and expectations. (In: Fee, E and Fox, DM eds. 1988: AIDS: the burdens of history. Berkeley: University of California). SAAYMAN, W \& KRIEL, J 1992: AIDS: the leprosy of our time? Towards a Christian response to AIDS in Southern and Central Africa. Johannesburg: Orion.

SNYMAN, HA 1999: The relationship between self-disclosure and psychological distress in asymptomatic HIV positive long-term survivors. Unpublished MA dissertation: Braamfontein: University of the Witwatersrand.

SONTAG, S 1991: Illness as metaphor. New York: Penguin. 
SOUTH AFRICAN HEALTH REVIEW 2000: Durban: Health Systems Trust.

STREBEL, A 1992: There's absolutely nothing I can do, just believe in God. South African women and AIDS. Agenda, 12:50-62.

TEGIUS, A \& AHMED, PI 1992: Living with AIDS: an overview. (In: Ahmed, PI ed. 1992: Living and dying with aids. New York: Plenum). UNAIDS 1999: AIDS epidemic update: December 1999. Geneva: WHO.

UNAIDS 2000: Report on the global HIV/AIDS epidemic. Joint United Nations programme on HIV/AIDS. Geneva: WHO.

UNGVARSKI, PJ \& FLASKERUD, JH 1999: HIV/AIDS: a guide to primary care management. Philadelphia: WB Saunders.

VAN DYK, AC 2001: Traditional African beliefs and customs: implications for AIDS education and prevention in Africa. South African Journal of Psychology, 31 (2):60-66.

WATNEY, S 1987: Policing desire: pornography, AIDS and the media. Minneapolis: University of Minnesota.

WEBB, D 1997: HIV and AIDS in Africa. Pietermaritzburg: University of Natal.

WILTON, T 1997: Engendering AIDS: deconstructing sex, text and epidemic. London: Sage. 